\title{
The Impact of Tourism on Business Development in Mountain Regions: A Case Study
}

\author{
Submitted 21/12/18, $1^{\text {st }}$ revision $13 / 1 / 19,2^{\text {nd }}$ revision 20/2/19 accepted 26/3/19
}

\author{
Merab Putkaradze ${ }^{1}$, George Abuselidze ${ }^{2}$
}

\begin{abstract}
:
Purpose: The article examines the potential of touristic and recreational resources of the mountain of Ajara (Georgia) and the territorial organization of tourism development dynamics on the basis of a sustainable system in the region.

Design/methodology/approach: In order to achieve the study outcomes, the priorities of tourism development in study region under the rational nature management conditions were defined by means of quantitative and qualitative indicators of traditional methods, sociological studies, balanced theory and the coordination failure theory.

Findings: The paper covers the resource potential existing in the region, which might be involved in tourism business development and is confirmed in businesses' structural adjustment in an attempt to increase the efficiency of social-economic development.

Practical implications: On the background of worsened the ecological and social-economic condition in the region, the ways solving the existing issues are grounded by rational nature management methodology.

Originality/Value: On the basis of lack of land, the existence of ecological problems and seasonal unemployment of labor on the basis of assessment of natural and resource potential of the region the efficiency of businesses' structural adjustment and tourism perspectives are shaped and proposed.
\end{abstract}

Keywords: Tourism, resource potential, business development, Georgia.

JEL codes: O18, R11, Z31, Z32, Z33, Z38.

Paper type: Research article.

\footnotetext{
${ }^{1}$ Batumi Shota Rustaveli State University, Professor, Department of Geography, merab.putkaradze@bsu.edu.ge

${ }^{2}$ Batumi Shota Rustaveli State University, Professor, Head of Finance, Banking and Insurance Department, Faculty of Economics and Business, corresponding author, george.abuselidze@bsu.edu.ge
} 


\section{Introduction}

The economy of mountain regions in the state of Georgia is developing with worsening tendency, which needs a complex study and setting the ways to solve the existed issues for a sustainable development by foreseeing the world's proper experience (Gunya, 2015; Huber et al., 2005; Koulov et al., 2016; Messerli, 2012; Nicilovic, 2011; Wehrli, 2014; Weingartner, 2016; Zhelezov, 2011). Coming out of this, the main aim of the study is to define the impact of tourism on business development in an example of mountain regions of the world (Bramwell et al., 1993; Bramwell et al., 2011; Gugushvili et al., 2017; Mowforth and Munt, 2003; Safranov, 2017; Zografos and Allcroft, 2007) and by foreseeing the acquired results to implement the sustainable development into the study area. In order to reach the aim set, the resolution of the following tasks is necessary:

$\checkmark$ Assess the potential of touristic-recreational resources of mountains of Ajara and their usage level;

$\checkmark$ Study the tourism industry`s development level and the role in tourism`s development;

$\checkmark$ Establish tourism types, its geography and development originalities;

$\checkmark$ Assess the place of existing resorts in social-economic development of the region;

$\checkmark$ Set the ways of tourism potential's increase and rise of its role in region`s business development.

The study takes the case of the mountain of Ajara (the municipalities of Keda, Shuakhevi and Khulo), an area which is equal to $1750 \mathrm{sq}$. km, with 57,1 thousand people. The above mentioned mountains are located at the Autonomous Republic of Ajara in Georgia.

\section{Literature Review}

The study of existing literature about sustainable development (Bell \& Morse, 2004; Dodds, 2007; Logar, 2010; Diakonidze, 2019) consider that tourism will reach a high sustainability level if all the interested parties participate in its development. If we foresee the wide interest existed towards the interested parties and the increase of its importance in numerous fields, the need of a well-developed theory of interested parties rises. Notwithstanding the fact, that the theory of interested parties exists, its current values might be set under the question and it is possible to foresee other organizational theories in practice, in particular the balanced theory and the coordination failure theory. Under the balanced theory, tourism is considered as a main motional (locomotive) power together with other economic sectors (Cooper et al., 2008). We consider, that tourism is assigned with such a big role, because of its multi-connections with other fields and these connections are more wide, rather those which are owned by other economic trends. The same is confirmed by coordination failure theory, according to which the economy is similar to eco-system 
and accordingly in order to ensure its organized operation, it is necessary to function all the components in an agreed manner (Cooper et al., 2008, p. 249).

Notwithstanding the fact, that in particular situations it is possible to distinctly analyze the problem and make the proper decision, the recent decade has revealed, that settled "usual business approach" has worsened already the unstable situation. In order to reach more beneficial results, the researchers support a joint approach in organizational management, planning and development process (Healey, 1998; Wahab \& Pigram, 1998; Bramwell \& Sharman, 1999). Also urgent becomes the management of sustainable development tourism or management of particular structures and activities to reach the desirable results (Bramwell \& Lane, 2011).

The major part of the existed literature about the sustainable tourism supports the importance to focus on local level to achieve the sustainability (Hunter, 1997). Tourism activity closely ties physical and geographic (territory) and abstract (social factors) spaces. The stipulation of location implies the fact that it is impossible to neglect the diversity of circumstances, which are needed to foresee each and every aspect of a given situation. It is known, that in order to study and analyze the different aspects of development, the collection of information should be performed by those people, which will be affected by tourism development or they are able to influence over tourism development by themselves (Abuselidze \& Devadze, 2018).

It is asserted, that tourism`s sustainable development actually needs the following: "planning, development and operation of the tourism should be cross-sectional and integrated, which covers the involvement of different state departments, public and private sector companies, public groups and experts" (Wahab \& Pigram, 1998, p. 283). Moreover, the following was declared at the Millennium Conference of Tourism Leaders (held in Osaka, Japan in 2001) the development of sustainable tourism is only possible by its support and involvement on local level by foreseeing that the development's main principle became the support and the participation of the local society (Abuselidze \& Devadze, 2018).

\section{Research Methodology}

Social and economic development of mountain regions of the world constitutes one of the significant issues of modern life, settlement of which (as a result of municipal programs) has not a big effect. Accordingly, in order to solve the issue, the following is needed: complex scientific study, share of existing experience in the world and set the sustainable development activities on the study territory by using different methods. Together with qualitative and quantitative methods, more and more popular becomes the social researches and case researches. For an analytical research it is also important the observation, a deepened interview and data modelling, gradation testing, multidimensional modelling, using the Geoinformation systems and methods of computer simulation (Lu \& Nepal, 2009, p. 11). 
Together with qualitative and quantitative methods, the methods of deepened interviews were used during the field observation, as a result of which the touristicrecreational resources of the study area, assimilation level of tourists conductivity were assessed and further usage perspectives were established. The tourism increase perspectives were defined by using the assessment and tourists' conductivity potential method (Birjhakov, 2008; Metrevel, 2008) and by foreseeing the rational nature management principles. According to balanced theory method (Cooper et al., 2008) the business development of the study area is discussed not only according the connection towards the particular field, but according the connection between all fields, as a result of which the existing fields` development perspectives were defined. By using the coordination failure theory (Cooper et al., 2008) there was found out the particular fields` development perspectives and study region`s further business development routes were set by the touristic business development priorities.

\section{Findings and Discussion}

\subsection{Assessment of touristic-recreational potential in the mountains of Ajara}

Some region`s business development and increase of population`s welfare by impact of tourism is firstly depended on the potential of touristic-recreational resources. The unity of natural and social-economic Geo-systems (which can be used for tourism activity) are meant under the touristic-recreational potential (Birjhakov, 2008; Metrevel, 2008). Main touristic-recreational resources of mountains of Ajara are represented in wonderful natural landscapes where the relief, inland waters and flora creates exotic show and fresh air and comfortable temperature during the summer period - the best conditions for travel and rest.

Thus, tourist destinations such as countries, regions, and cities make efforts and use funds to improve their tourist image and attractiveness. Regions which are attractive as tourist destinations benefit from increasing number of tourists, build their competitive advantage over other regions and contribute to the economic performance of the region (Abuselidze \& Johann, 2015). Region`s attractiveness refers to attributes which tourists consider as important. Attributes for tourism destinations include natural resources (e.g., climate, landscape), cultural/heritage resources (e.g., history, music, paintings), functional/physical resources (e.g., accommodations, food, transportation) and others (Dwyer and Kim, 2003).

Today, when we talk about the development of sustainable tourism, the special urgency is applied to such trends, like cultural tourism, while the introduction and share of traditions, distinctive character of particular region or commune rises up (Lu and Nepal, 2009). The main natural sightseeing of Ajara region is Makhuntseti waterfall, which is located near the central highway, $25 \mathrm{~km}$ away from the city of Batumi. Because of waterfall's geographic location, annually, in the summer period it is visited by 47-50 thousand tourists according to the Department of Tourism and 
Resorts of Ajara. Besides, adjacent to waterfall, on the roads of ravine, there are arch-type rock bridges made in XII century (Abuselidze, 2004) and modern hydrotechnical structures, which inspires a big interests from the visitors.

The resort Beshumi is located $100 \mathrm{~km}$ away from the city of Batumi on $1950 \mathrm{~m}$ above sea level and it constitutes a significant touristic-recreational resource of mountains of Ajara. The main sightseeing of resort is amazing natural landscapes, where the best thermal period for rest comes during the summer period. Resort is used by in average 5000-5500 recreants. Winter resorts Gomarduli and Goderdzi are located 80-100 km away from Batumi city. The natural conditions for development of mountain-ski tourism and increasing number of tourists on the resorts guarantees, that in near future they might became the resorts of international importance.

The best conditions to develop an ecotourism are in mountains of Ajara, where a wine and rural tourism is already marked by this time. Wine houses, located adjacent to the central highway and touristic routes of mountains of Ajara, $15 \mathrm{~km}$ away from the city of Batumi are known for their constantly increasing visitors. The main resource for rural tourism development are beautiful natural landscapes, ecologically pure environment, historical monuments, local culture, traditions, cuisine, etc. Mainly the foreign tourists are interested in rural tourism and their number are increasing year by year (Putkaradze \& Gorgiladze, 2015; 2016). The rafting is a new type of tourism and notwithstanding the fact, that it was formed only two years ago, it develops with quite intense pace. Riv. Atcharistskali possess all the natural resources necessary to develop the rafting, which is also connected to other types of tourism and under this scope of view, there are a huge perspectives of its further development.

In the mountains of Ajara, the mineral waters are almost in every ravine and village, most of which are not studied yet. In the past, population used majority of mineral waters for healing and treating purposes and they were achieving best results. In modern terms, the mineral waters are rarely used. It can be said, that by using the mentioned resource, it is possible to develop the recreational tourism.

Since regions vary in terms of their natural, cultural, historical and functional resources, some of them appear as more attractive than others. However, appropriate tourism management and activities performed by the local authorities and involvement of local businesses and societies can enhance the attractiveness of regions. Additionally, the activities leading to the development of a unique value proposition for a specific region need to be synchronized with the national marketing activities aimed at creating a country brand (Abuselidze \& Johann, 2015).

According to Cunha et al. (2005) the main hypothesis of local region and commune development during the tourism impact's assessment is how the increasing tourism activity ensures the sustainable development with such positive outcomes, like creation of jobs, increase of income and improve of population`s residential 
conditions. On the basis of study the potential of touristic-recreational resources there is found out, that existing potential is less likely involved in business turnover, and in case of its complex usage, the role of tourism in local business development would be much higher. As a result of qualitative and quantitative study, there was revealed, that tourists (mostly foreign ones) especially are interested and attracted with Georgian culture, local hospitality, Georgian cuisine, that, according to the interviewee`s application, often constitutes the purpose of tourists repeated visits.

During the region's study, in order to acquire the right outcomes about field's economic development, human resources or geographic condition, it is crucial to choose, group the participating structures or stakeholders and study their influence. Stakeholders are business groups, local population, government structures and tourists themselves, which have made their contribution in the given region's tourism development (Cooper et al., 2008, p. 687).

\subsection{Tourism industry's development}

Tourism development is highly depended on tourism industry, which defines the touristic flows and their requirements. Tourism industry in mountains of Ajara is under formation process, where the priorities are granted to accommodation places and tourism infrastructure development. The serious works were performed in this field on mountain-ski resort Goderdzi, where the ski traces and cableways of international standards were arranged. Several hostels are already operating but comparing to resort's potential, the infrastructure cannot satisfy the increasing demand. The tourism industry of resort "Gomarduli" is slightly weakly developed, where some hostels function quite well. Ski traces are not completely arranged yet (in near future, it is planned to construct $3 \mathrm{~km}$ length ski trace with own cable way).

The accommodation objects in resort "Beshumi" are individual houses, total amount of which equals to 950 unit. The comfort level of these houses are low. They are unable to satisfy the modern requirements and they mainly are used by owners. According the data of qualitative and quantitative study, only $38 \%$ of tourists consider the low quality service as lack of tourism industry and those visitors, who possibly will not return to Ajara states they consider the low service as one of the reasons. The complaint about infrastructure and roads was made only from 72 of visitors (17\% of the questioned people).

During the definition of service quality on tourism market, we rely on models of Gronroos, C., also on the models of Parasuraman, A., Zeithaml, V.A, and Berry, L, which define the service quality according to consumer's satisfaction level or by meeting the offered service with visitors` expectations (Cooper et al., 2008). The said has showed us that the development of rural tourism is being hindered by low quality service, lack of touristic routes, incomplete information base, the difficulty in transport availability and other. We consider there should be performed intense works in order to improve the infrastructure as building and maintaining a strong 
country brand brings positive effects to all sectors of the economy and is crucial for the enhancement of a country's position in the global marketplace. Considering the global character of competition, an attractive country brand should be able to attract foreign investments, businesses and skillful workforce as well as support exporters and promote public diplomacy. It must also promote the goals of the tourism industry and strengthen national identity and increase self-respect (Moilanen \& Rainisto, 2009).

\subsection{Tourism types and geography}

By studying the potential of touristic-recreational resources of mountains of Ajara it is obvious that in the mentioned region exist natural-geographic and historicalcultural conditions to develop the tourism, but its realization needs the definition of types of tourism and geography of tourists` flows. Currently, the type of region`s main tourism is cognitive (ecotourism), recreational and mountain-ski tourism. According to official statistical data, the number of tourist on study area during the recent 5 years was increased from 4.850 to 9.470 or by 1.9 times, while the amount of visitors reached 46,6 thousand. The big difference between the visitors and tourists of region is firstly caused by the fact, that most of visitors coming as tourists of Ajara sea coast regions, are highly interested with natural landscapes of mountains of Ajara and local culture. From another side, the mentioned scales are caused by study area touristic objects` close location to city of Batumi (15-100 km).

One of the old types of tourism is recreational tourism, which is developed in mountain-ski resort Beshumi. During the summer season, resort is used by 50005500 recreants, which mainly reside at their own houses. Accordingly, the role of such types of holiday-makers in regional economy`s increase is quite low.

The mountain-sky tourism is being developed quite dynamically, which was formed as Goderdzi and Gomarduli resorts several years ago. The number of tourists on the resorts are increasing year by year and in average it equals to 3800 tourist (54\% of which comes on Goderdzi resort). The resorts have big development perspectives as it is located $75-100 \mathrm{~km}$ away from the city of Batumi, while the country`s leading mountain-ski resort Gudauri is located $350 \mathrm{~km}$ away from the city.

Ecotourism, which is formed as rural tourism and wine tourism, gradually increases. The main object of wine tourism is "Ajarian Wine House", where the wine museum is located and exists the possibility to taste different types of wines. The wine tourism involves foreign and local (just married) visitors, amount of which do not exceed 20.5 thousand viewers.

The development of rural tourism is based on various, exotic natural landscapes, historical monuments and cultural heritage, tasting of local dishes made of pure agriculture products, introduction with folk and ethnographic originalities, visiting 
the picnic places and other. Nine urban tourism route operates in mountains of Ajara now.

In Keda municipality the wine tours (village of Atcharistskali, Vaio, Gegelidzeebi, Dandalo, Pirveli Maisi, Koromkheti), the Zendidi and Merisi ravine rural tour and Gobroneti and Mount Latevri routes. In Shuakhevi municipality the Mount Chirukhi adventure tour and Nigazeuli rural touristic tour. In Khulo municipality the Goderdzi - Green lake - Beshumi, Thago - Skhalta walking tour and Skhalta - Khikhani historical-cultural routes. The visitors involved in rural tourism exceeds 26,6 thousand on average (they spend several hours in the region).

Rafting, was established in 2017, constitutes a new type of tourism, which is developed at Riv. Atcharistskali located in Keda municipality. The route begins at area adjacent to Makhuntseti waterfall and continues $6 \mathrm{~km}$ distance along the river flow. According to data in 2018, 8070 visitors have used this type of tourism and the income exceeded 105 thousand USD. The region holds its development's huge potential.

\subsection{Tourism potential's usage perspectives}

In order to find out tourism development in mountains of Ajara, first, we should define the qualitative and quantitative indicators of usage of study territory's touristic-recreational resources. For this purpose, the region`s touristic conductivity potential should be defined, which implies the area's loading with tourists by such touristic load, which can be handled with this or that touristic objects without serious damage of local resources, without negative impact and social-economic issues in the population (Birjhakov, 2008; Metreveli, 2008).

The definition of conductivity potential of the study area could be possible an example of currently existing tourism objects: Gomarduli, Goderdzi and Beshumi. According to 2017 data, the number of tourists in Gomarduli was 1750, in Goderdzi 2065 and in Beshumi 5500. By foreseeing the tourists conductivity potential, the mentioned resorts (at their maximum) during the season can handle 4700 tourists in Gomarduli, 5500 tourists in Goderdzi and 12500 tourists in Beshumi. In case of use of touristic-recreational potential (without breaking the ecological balance) existed on the resorts and in case of expanded tourism industry (under our calculations and projecting data of Department of Tourism and Resorts of Autonomous Republic of Ajara regarding the tourism`s further development in mountain regions) Gomarduli can handle about 12000 tourists, Goderdzi 25000 tourists and Beshumi 40000 tourists (Figure 1).

The study area possess quite big perspectives for tourism development, but for its development in the scope of other fields of business, it is needed to confirm their development abilities by using different types of economic methods and prioritize them. 
Figure 1. Business field structure of mountains of Ajara (2017) and its change in case of touristic business development

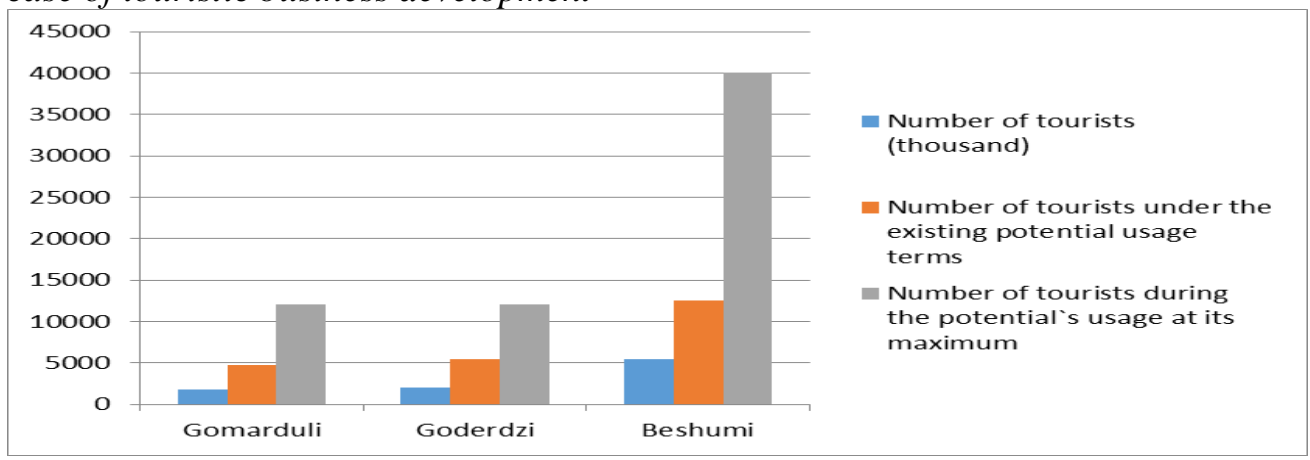

Source: Authors' calculations.

According to balanced theory (Cooper et al., 2008) the regional economy`s increase in order to define the possibility of existing fields` development towards each other, it is needed to find out the perspectives of a particular field. The leading field in mountains of Ajara is agriculture, where not less than $60 \%$ of labor resources are employed and produces approximately 55-60\% of the regional GDP. Because of scarce land resources (approximately 550 sq. m arable land per one man), it is impossible to reach big perspectives in said field`s development. Accordingly, agriculture's extensive character needs increase of land resources, but there is no actual possibilities to extend it. Moreover, the use of land resources is often by violating the basic principles of rational natural usage, where the elemental processes take place and the ecological conditions worsen.

The water resources are quite rapidly used for hydro power engineering development purposes. During the recent years, serious foreign investments were made in order to develop the said field, thus the hydro-potential was actually assimilated and there is no perspectives for further development.

Food industry is weakly developed and its further extension (because of restricted base of raw products) for now has no perspectives. The business fields in the region are actually developed separately from each other, so this will not contribute much to economy`s increase. Coming out of this and on the basis of the study area`s basic business fields` analysis, there is found out that the region`s business development by using the balanced theory has a big perspectives.

By assessing the study area's natural and resource potential and discussing the existing business fields, it is found that priority for increased regional economy should be granted to coordination failure theory, on the basis of which tourism should become one of the leading fields of business. For its development the following perspectives must be fulfilled: 
1. Region is rich with touristic-recreational resources, which are less likely involved in business turnover and in case of its rational use, no serious ecological issues will be occurred in environmental condition;

2. The geographic location of mountain-ski resorts on study territory. Comparing to similar resorts of the country (Bakuriani, Gudauri), it has a huge priority (in transportation distance) for tourists in Western Georgia, especially in city of Batumi and Ajara region;

3. One of the main priority of tourism development is, that it does not contradict none of the business fields` development. Moreover, in case of development of mountain-ski tourism, the seasonally free population will be employed;

4. Tourism increase will further increase the production of ecologically pure agriculture local products (meat, milk, fruits, vegetables, honey) and enhances the material condition of village populations;

5. Tourism development will encourage holding the population in the villages, promote their employment and increased income.

In order to evidence the tourism development priorities on the study territory, we need to imagine the types of tourism and current stages of resorts development, then to support its further development potential. We suppose, that mountain-ski tourism possesses a huge potential in region's material security (Figure 1). According to evaluations of the recent years, the amount of tourists involved in this type of tourism is gradually increasing. The realization of its potential is especially possible by means of Goderdzi resort, which has the following priorities:

1. It is located close to Batumi-Akhaltsikhe highway, a highway of international importance, $100 \mathrm{~km}$ away from the city of Batumi, while the similar resort Gudauri is $350 \mathrm{~km}$ away;

2. The resort is located at the top of the mountain ridge and on Goderdzi pass, from where the beautiful landscapes of mountains of Ajara are seen;

3. The resort's relief, inclination of the ridge and ski route length meets with international standards;

4. Climate conditions and snow thickness gives the possibility to operate the resort during 3 months;

5. Permanent village settlements are observed near (4-5 km away from) the resort, which is seasonally free population can be employed in the resort. Mountain-ski resort Gomarduli has also some particular perspectives, which is laid on close location from Batumi $(75 \mathrm{~km})$ and with existing natural, environmental potential.

Resort Beshumi holds big opportunities to develop recreational tourism. The mentioned resort's potential is as follows:

1. It is situated 1900-1950 m above the sea level, close to Batumi-Akhaltsikhe highway (1.5 km away from Goderdzi resort), from where the tourists can easily reach by transport from seaside regions; 
2. It is located at climate-splitting zone, where comfortable thermal conditions are observed during the spring period (relative humidity at seaside is $81-82 \%$, while in Beshumi it is $60-62 \%$ );

3. Resort's exotic landscapes, natural terms and resources (cold springs, forest) gives the best condition to turn into recreation object of international standards in the nearest future.

Rural tourism gradually develops and diverse resources for its further development actually exists almost in every villages. The priority in extension of this types of ecotourism should be given to creation of new routes, which will allow tourists to visit all natural and social-economic sightseeing along one ravine (Atcharistskali, Merisi, Tchvana, Mareti, Skhalta, Ghorjomi). In case of execution of mentioned projects, the village infrastructure will be improved, the local population will be employed more, the need of natural, ecologically pure agricultural products will be enhanced and there will be plenty of opportunities to hold the population in the villages.

The development of new type of tourism rafting, has a big perspective, considering the fact, that it is bound with wine house and Makhuntseti waterfall touristic objects, where the tourist is involved in cognitive and extreme tourisms at the same time. Such multi-field involvement of the tourists will finally cause a positive impact on touristic flow`s increase.

The study area is rich with diverse mineral water, which is a cause to develop a recreational tourism. These mineral waters are not involved in business turnover yet. The population use the existing resources for healing purposes. The fundamental study should be performed in this direction, which sets a huge opportunities to create the recreational touristic objects. It should be mentioned that tourists` increase in study region is possible with flexible management on account of 1-2 day tours of maritime tourist (in average, the Batumi beach hosts 220000 tourists), thus Batumi with its beaches will be unloaded somehow (Putkaradze \& Khorava, 2018) and from another side, the tourists will be given a chance to rest and enjoy pure environment of mountains of Ajara.

In case of using the touristic-recreational potential of mountains of Ajara at its maximum, the regional field structures will be seriously changed as the specific share of tourism industry will be highly increased (Figure 2). The development of mountainous tourism from one side encourages the local resources involvement into business turnover in rational natural management scope and from another side the sustainable development of the mountains will be performed, the material security of population will be enhanced and then the stability of demographic processes will be commenced. Sustainable development of mountain regions present one of the most urgent problem of modern life. The solution needs the complex study of naturalgeographic and social-economic factors and setting of particular tasks. 
Figure 2. Business field structure of mountains of Ajara (2017) and its change in case of touristic business development
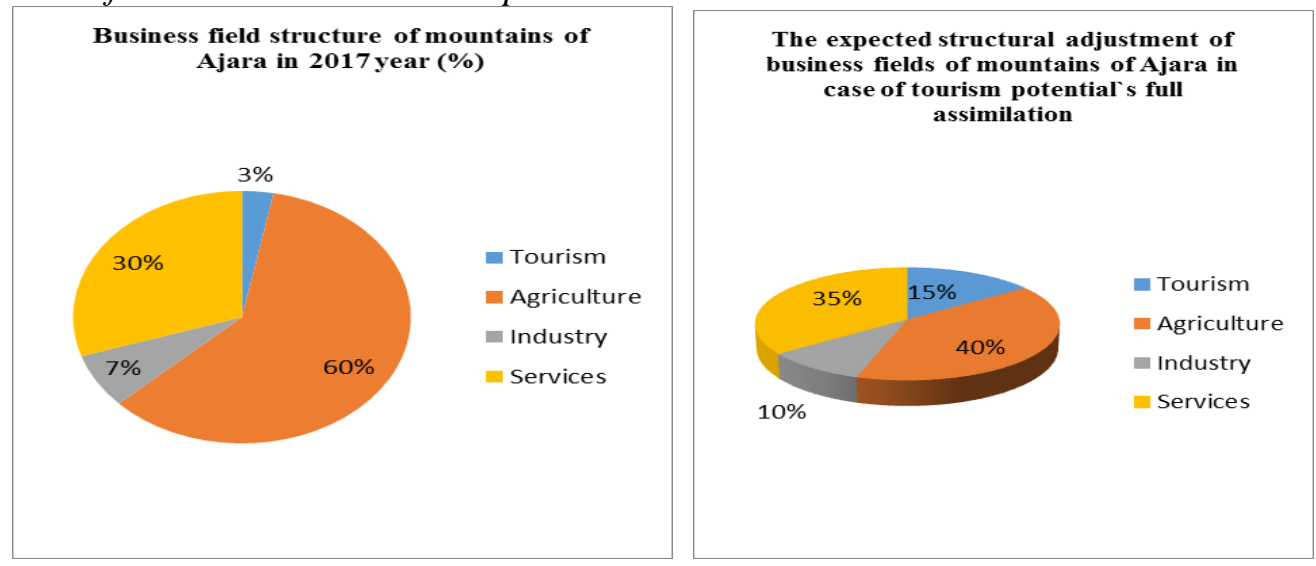

Source: Authors' calculations.

Accordingly, the mountain regions` specific problems needs global approach and local action. Under the analysis of business study of mountain regions of Ajara, there was found out, that the leading field of the region is agriculture, but its further development is impossible due to scarce land resources and among ecologically worsened terms. The water resources are used at their maximum, but there is no conditions necessary to develop processing industry while the existed touristicrecreational resources are poorly used. According to field observations and using different types of theoretical methods that were defined on the basis of existed natural and social-economic Geo-systems for regional economy`s increase, the priority should be given to tourism.

Comparing the amount of tourists and tourism conductivity potential of mountains of Ajara, there was found out that only 5-6\% out of existing resources are used for now. Big perspectives from tourism development priorities has mountain-ski tourism, which presents the most optimal types of business activity on the background of scarce land resources and ecologically stressed region. From another side, in winter period it will promote the local population's seasonal employment and will serve as stimulator in mountain`s infrastructure operation. Besides, no other type of tourism has more perspectives.

\section{Conclusion}

As a result of assessment of existing natural resources potential of mountains of Ajara and the study of development perspectives of business fields, there was found out, that on the background of scarce land resources and worsened ecological conditions, tourism should become the leading trend for study area's sustainable development. Existing resources potential`s usage and increased touristic dynamics define and confirm that the region has an increased perspective of tourism 
development. Accordingly, the maximum involvement of touristic-recreational resources into business turnover is much depended on tourism infrastructure improvement, which itself depends on the right management and state subsidies.

The biggest role in solving the tasks set towards the sustainable development of mountain regions should be played by "a program of tourism development in mountain regions" acting in the whole country, which is declared as one of the priorities enhancing the country`s economy.

\section{References:}

Abuselidze, G. 2004. South-western Georgia of Tbel Abuseridze epoch (economic situation). Georgia: Publishing House of Science.

Abuselidze, G. \& Johann, M. 2015. Creating the Unique Destination Proposition (The Case of Poland).

Abuselidze, G. \& Devadze, N. 2018. Stakeholders and their role in sustainable tourism development. Biannual International Scientific Practical Conference, SEU ISC.

Bell, S. \& Morse, S. 2004. Experiences with sustainability indicators and stakeholder participation: A case study relating to a 'Blue Plan' project in Malta.

Birjhakov, M. 2008. Theory of Tourism. Tbilisi. p. 270.

Bramwell, B. \& Lane, B. 1993. Sustainable tourism: An evolving global approach. Journal of Sustainable Tourism, Vol. 1, No. 1, pp. 1-5.

Bramwell, B. \& Sharman, A. 1999. Collaboration in local tourism policy-making. Annals of Tourism Research, 26.

Bramwell, B. \& Lane, B. 2011. Critical research on the governance of tourism and sustainability. Journal of Sustainable Tourizm.,Vol. 19, No. 4/5, pp. 411-421.

Cooper, C.P. 2008. Tourism: principles and practice. Harlow: Pearson Education.

Da Cunha, S.K. \& Da Cunha, J.C. 2005. Tourism Cluster Competiveness and Sustainability: Proposal for a systematic Model to Measure the Impact of Tourism on local Development. Brazilian Administration Review, Vol. 2, No. 2, pp. 47-62, http://dx.doi.org/10.1590/S1807-76922005000200005.

Diakonidze, M. 2019. Development of Tourism Services and Employment Perspectives: A Case Study. European Research Studies Journal, 22(3), 132-148.

Dodds, R. 2007. Sustainable tourism and policy implementation: Lessons from the case of Calvia, Spain. Current Issues in Tourism, Vol. 10, No. 1, pp. 296-322.

Dwyer, L. \& Kim, Ch. 2003. Destination Competitiveness: Determinants and Indicators. Current Issues in Tourism, Vol. 6, No. 5.

Gugushvili, T., Salukvadze, G. \& Salukvadze, J. 2017. Fragmented development: Tourismdriven economic changes in Kazbegi, Georgia. Annals of Agrarian Science, Vol. 15, No. 1, pp. 49-54.

Gunya, A.N. 2015. Socially oriented concepts and approaches in a research of mountain territories of the Caucasus and ensuring sustainable development. Sustainable Development of Mountain Territories, Vol. 3, No. 25, pp.15-22.

Healey, P. 1998. Collaborative planning in a stakeholder society. Town planning review, Vol. 69, No. 1.

Huber, U., Bugmann, H. \& Reasoner, M. 2005. Global change and mountain regions: an overview of current knowledge. Dordrecht, the Netherlands Springer. 
Hunter, C. 1997. Sustainable tourism as an adaptive paradigm. Annals of Tourism Research, Vol. 24, No. 4, pp. 850-867.

Koulov, B. \& Zhelezov, G. 2016. Sustainable mountain regions: Challenges and perspectives in Southeastern Europe. Springer International Publishing.

Logar, I. 2010. Sustainable tourism management in Crikvenica, Croatia: An assessment of policy instruments. Tourism Management, Vol. 31, No. 1, pp. 125-135.

Lu, J., \& Nepal, K. 2009. Sustainable Tourism Research: An Analysis of the Papers Published in the Journal of Sustainable Tourism. Journal of Sustainable Tourism, Vol. 17, No. 1, pp. 5-16.

Messerli, B. 2012. Global change and the world's mountains. Mountain research and development, 32(S1), pp. S55-S63.

Metrevel, M. 2008. Tourism and Environment Protection (Basics in Ecotourism). Tbilisi, p. 204.

Moilanen, T. \& Rainisto, S. 2009. How to Brand Nations, Cities and Destinations. A Planning Book for Place Branding. Great Britain, Palgrave and Macmillan.

Mowforth, M. \& Munt, I. 2003. Tourism and sustainability: Development and new tourism in the third world ( $2^{\text {nd }}$ edition). Routledge, London, UK.

Nicilovic, V. 2011. Demographic limits to sustainable development of mountain regions in Serbia. Sustainable development in mountain regions; Southeastern Europe. Springer.

Putkaradze, M. \& Gorgiladze, N. 2015. Ecological Problems of Ecotourizm in Adjara. Iv. Javakhishvili, Tbilisi State University, Faculty of Exact Natural Sciences, Department of Geography, Institute of Applied Ecology, FENS, TSU. International Conference Applied Ecology: Problems, Innovations. Proceedings ICAE, pp. 189-191.

Putkaradze, M. \& Gorgiladze, N. 2016. Tourism and Ecology in Adjara. International Journal of Environmental Sciences, Vol. 5, No. 2, pp. 86-88.

Putkaradze, M. \& Khorava, S. 2018. Tourism Industry's Influence on Recreational Zone's Ecological Condition in the Seaside of Adjara. Journal of Tourism and Hospitality Management, Vol. 6, No. 1, pp. 25-32.

Safranov, T.A. 2017. Natural compound of recreational and tourist potential of the Ukrainian Carpathians. Journal Sustainable Development of Mountain Territories, 9-3(33), pp. 250-256.

Wahab, S. \& Pigram, J.J. 1998. Tourism and sustainability: Policy considerations. In S. Wahab and J.J. Pigram (eds) Tourism, Development and Growth. The Challenge of Sustainability, 277-290. London: Routledge.

Weingartner, R. \& Gunya, A.N. 2016. The value of mountains and the need for active participation in the international mountain programmes. Journal Sustainable Development of Mountain Territories, Vol. 2, No. 8, pp. 120-126.

Wehrli, A. 2014. Why mountains matter for sustainable development. Mountain research and development, Vol. 34, No. 4, pp. 405-409.

Zhelezov, G. 2011. Sustainable development in mountain regions; Southeastern Europe. Springer.

Zografos, C. \& Allcroft, D. 2007. The Environmental Values of Potential Ecotourists: A Segmentation Study. Journal of Sustainable Tourism, Vol. 15, No.1, pp. 44-66. 